\title{
Perbedaan Sekuens Asam Amino Epitop Sel B dan SelT pada Protein Hemaglutinin [H] Antara Virus Gampak Liar dan Virus Vaksin di Indonesia
}

\author{
Made Setiawan, * Agus Sjahrurachman, ** Fera Ibrahim, ** Agus Suwandono *** \\ ${ }^{*}$ Rumah Sakit Penyakit Infeksi Sulianti Saroso, ${ }^{* *}$ Bagian Mikrobiologi FK-UI, ${ }^{* * *}$ Litbangkes Departemen \\ Kesehatan RI
}

Latar belakang. Protein $\mathrm{H}$ virus campak sangat penting agar virus dapat menginfeksi sel pejamu. Selain itu, protein $\mathrm{H}$ dapat merangsang antibodi spesifik yang dapat menetralisasi virus campak, sehingga virus tidak dapat menginfeksi sel. Bila ada perbedaan sekuens asam amino epitop sel B dan sel T pada protein $\mathrm{H}$ antara virus campak liar dan virus vaksin campak, maka vaksin tidak dapat merangsang terbentuknya antibodi protektif.

Tujuan. Mengetahui perbedaan sekuens asam amino epitop sel $\mathrm{B}$ dan sel $\mathrm{T}$ pada protein $\mathrm{H}$ antara virus campak liar (G2, G3, dan D9) dan virus vaksin CAM-70, Schwarz dan Edmonston-wt.

Metode. Ekstraksi dan amplifikasi gen dilakukan di laboratorium menggunakan teknologi biologi molekuler dan analisis gen dan protein dilakukan menggunakan teknologi bioinformatika.

Hasil. Ditemukan perbedaan sekuens asam amino epitop sel $\mathrm{T}$ pada protein $\mathrm{H}$ antara virus campak liar dan virus Edmonstone-wt, sedangkan antara virus campak liar dan virus vaksin (CAM-70 dan vaksin Schwarz) tidak ditemukan perbedaan. Ditemukan perbedaan sekuens asam amino pada epitop sel B protein $\mathrm{H}$ antara virus campak liar dan virus vaksin (CAM-70 dan Schwarz, sedangkan antara CAM-70 dan Schwarz tidak ditemukan perbedaan.

Kesimpulan. Tidak ada perbedaan sekuens asam amino epitop sel $\mathrm{T}$ antara virus campak liar dan virus vaksin (Schwarz dan CAM-70). Perbedaan ditemukan pada epitop sel B antara virus campak liar dan virus vaksin (CAM-70 dan Schwarz). (Sari Pediatri 2008;10(3):190-5).

Kata kunci: virus campak, protein hemaglutinin, epitop sel T, epitop sel B.

\footnotetext{
Alamat Korespondensi:

Dr.dr. Made Setiawan SpA. Jl. Merah Jambu no.31-32 blok A3 Komplek Wali Kota Kelapa Gading Jakarta Utara. Hp. No. 081932331665.
}

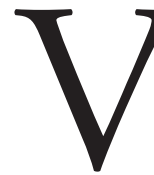

rus campak dapat menyebabkan penyakit akut pada anak yang dimulai dari traktus respiratorius bagian atas, selanjutnya menyebar ke organ dan jaringan, sehingga mengakibatkan berbagai gejala klinis. Virus campak dapat menginfeksi sel sistem imun seperti limfosit 
dan makrofag, dan dapat menekan sistem imun yang bersifat sementara. ${ }^{1,2}$

Virus campak adalah virus RNA untai tunggal negatif mengkode 6 jenis protein utama diantaranya 2 buah glikoprotein transmembran yaitu protein fusion (F) dan protein hemaglutinin $(\mathrm{H}){ }^{3}$ Agar virus dapat menginfeksi sel diperlukan kerja sama antara kedua protein tersebut. Protein F bertanggung jawab untuk melakukan fusi antara dinding virus dengan membran sel pejamu dan untuk penetrasi virus, sedangkan protein $\mathrm{H}$ berfungsi untuk perlekatan virus melalui interaksi dengan reseptor yang ada pada permukaan sel pejamu. Glikoprotein $\mathrm{F}$ dan $\mathrm{H}$ bersama-sama berfungsi untuk mengadakan fusi antara virus dan membran sel pejamu, dan memfasilitasi masuknya virus ke dalam sel. ${ }^{4,5}$

Sistem imun pejamu yang terinfeksi virus campak memberi respons terhadap protein $\mathrm{H}$. Antibodi terhadap protein $\mathrm{H}$ dapat diukur dengan tes netralisasi infektivitas virus dalam biakan jaringan. Antibodi netralisasi memegang peranan penting dalam proses pencegahan penyakit. ${ }^{6}$ Sistem imun selular juga memberi respons terhadap protein $\mathrm{H}^{7}$

Variasi sekuens nukleotida gen $\mathrm{H}$ mengakibatkan timbulnya berbagai clade dan genotipe virus campak liar. ${ }^{8}$ Adanya variasi gen $\mathrm{H}$ mengakibatkan terjadi berbagai bentuk struktur protein $\mathrm{H}$ pada masingmasing clade atau genotipe, sehingga epitop pada masing-masing protein $\mathrm{H}$ akan berbeda-beda, yang pada akhirnya berpengaruh terhadap respons imun spesifik pada pejamu yang terinfeksi. ${ }^{9}$

Sampai saat ini di Indonesia dikenal 3 genotipe virus campak liar yaitu, G2, G3, dan D9. Jenis vaksin campak yang banyak digunakan adalah vaksin campak CAM-70 dan Schwarz. Virus vaksin campak CAM70 yang asli berasal dari virus campak galur Tanabe dari Jepang, sedangkan virus vaksin Schwarz berasal dari virus campak galur Edmonston yang diisolasi pada tahun 1954. Hasil penelitian memperlihatkan bahwa, sekuens nukleotida gen dari kedua vaksin ini berbeda. ${ }^{10}$ Semua virus campak liar akhir-akhir ini sudah mengalami penyimpangan genetik secara relatif bermakna terhadap virus vaksin maupun terhadap virus yang diisolasi pada tahun 1950 maupun pada tahun 1960. ${ }^{11,12}$

Penelitian bertujuan untuk menilai perbedaan sekuens asam amino epitop sel $\mathrm{T}$ dan sel $\mathrm{B}$ pada protein hemaglutinin antara virus campak liar dan virus vaksin campak yang ada di Indonesia.

\section{Metode}

\section{Bahan dan Cara Kerja}

Penelitian merupakan penelitian laboratorium, untuk menganalisis gen dan protein virus campak liar dan virus vaksin campak menggunakan teknologi biologi molekuler dan bioinformatika. Isolat virus campak liar G2, G3, dan D9 diperoleh dari Litbangkes Departemen Kesehatan RI, yang sebagian dari masing-masing isolat sudah dikirim ke ICDC (Atlanta-USA) dan genotipe isolat virus tersebut sudah ditentukan. Genotipe ketiga isolat virus campak liar tersebut ditentukan ulang di Indonesia. ${ }^{13}$

Ekstraksi RNA virus dilakukan dengan menggunakan QIAamp ${ }^{\circledR}$ Viral RNA Mini Kit dari QIAGEN (Catalog no.5204) sesuai dengan petunjuk yang diberikan oleh perusahaan. Primer yang digunakan, adalah primer yang dibuat berdasarkan analisis sekuens referensi galur Edmonston-wt, substrain AIK-C (Komase dkk) (AB046218) NCBI ${ }^{14}$ menggunakan program computer software Primer-3.

Reaksi Reverse Transcriptase (reaksi transkripsi terbalik) dilakukan menggunakan kit SuperScript ${ }^{T M} I I I$ Reverse Transcriptase (invitrogen) dengan cara sesuai dengan protokol yang diberikan oleh perusahaan. Sedangkan cDNA yang diperoleh sudah dapat digunakan sebagai template untuk amplifikasi PCR, cDNA yang diperoleh dari reaksi reverse transcriptase diperbanyak dengan metode PCR menggunakan platinum taq DNA polymerase (invitrogen). Produk PCR dideteksi menggunakan elektroforesis gel berdasarkan berat molekul atau panjang rantai nukleotida. ${ }^{15}$ Produk DNA dimurnikan dengan menggunakan kit QI Aquick Gel Extraction Purification (QIAGEN Cat. No.28704). Cara yang dilakukan sesuai dengan protokol yang diberikan oleh perusahaan.

Untuk melakukan cloning hasil PCR, maka digunakan TOPO TA Cloning kit buatan Invitrogen (Cat. No.K4500-01). Cara melakukan reaksi sesuai dengan protokol yang diberikan oleh perusahaan. Ekstraksi plasmid dilakukan sesuai dengan protokol yang diberikan oleh perusahaan QIAGEN dengan menggunakan kit QIAprep ${ }^{\circledR}$ Spin Miniprep (Cat. No. 27104). Filtrat dalam tabung mikrosentrifugasi yang diperoleh diberi label dan disimpan untuk sekuensing.

Sekuensing dilakukan dengan direct sequencing dari hasil PCR gen H. Pemeriksaan DNA disekuens dengan 
menggunakan automatic sequencer berdasarkan metode Sanger (dideoxy termination method). Reaksi tersebut dilakukan pada mesin automatic ABI PRISM® Big Dye Terminator Cycle Sequencing Ready Reaction kit. Primer yang dipakai untuk melakukan sekuensing sama dengan primer pada Tabel 1.

\section{Hasil}

\section{Epitop spesifik CTL (cytotoxic T lymphocyte) pada protein $\mathbf{H}$}

Pada protein $\mathrm{H}$ terdapat dua epitop spesifik CTL, yaitu asam amino 343-351 dan asam amino 544-552. Dari hasil penjajaran epitop 343-351 ternyata tidak ditemukan perbedaan urutan asam amino, dan semua isolat ditemukan mempunyai sekuens asam amino yang sama yaitu Asp-Pro-Val-Ile-Asp-Arg-Leu-Tyr-Leu. Pada penjajaran epitop asam amino 544-552 ditemukan perbedaan pada asam amino 546 yaitu asam amino
G (glisin) pada virus Edmonston-wt (Ser-Pro-GlyArg-Ser-Phe-Ser-Tyr-Phe), sedangkan pada genotipe G2, G3, D9, CAM-70, dan Schwarz adalah S (serin) (Ser-Pro-Ser-Arg-Ser-Phe-Ser-Tyr-Phe).

\section{Epitop Spesifik Sel B (antibodi) pada Protein H}

Epitop-epitop antibodi yang penting pada protein $\mathrm{H}$ adalah, asam amino188-199, 313-314, 309-318, dan 305-322. Epitop yang lain 49-72, 103-117, 123-137, 242-255, 293-307, 463-477. Dari hasil penjajaran asam amino pada epitop-epitop tersebut, tampak bahwa pada epitop 123-137 tidak ditemukan perbedaan, sedangkan pada epitop-epitop yang lain ditemukan beberapa perbedaan.

Perbedaan asam amino pada epitop 49-72, yaitu asam amino $61 \mathrm{P}$ (prolin) pada genotipe $\mathrm{G} 3$, sedangkan G2, D9, CAM-70, Schwarz dan Edmonston adalah H (histidin). Perbedaan epitop 103-117 ditemukan pada asam amino $117 \mathrm{~L}$ (leusin) pada Schwarz, sedangkan G2, G3, D9, CAM-70 dan Edmonston

Tabel 1. Primer digunakan untuk PCR dan sekuensing

\begin{tabular}{rrlr}
\hline No. & Nama Primer & \multicolumn{3}{c}{ Urutan nukleotida } & Posisi \\
\hline 7 & Primer H 1 & CAT CAA gCC CAC CTg AAA TTA TC & $7183-7205$ \\
& 2 & gAC ATg TTT gAg AAT TgA CCT CTg & $7852-7875$ \\
8 & Primer H 3 & CAT Tgg TgA ACT CAA CTC TAC Tgg & $7764-7787$ \\
& 4 & gAg TgC TTg gAT TTT ACC CTT ACA & $8425-8449$ \\
9 & Primer H 5 & gAT CCA gTg ATA gAC Agg CTT TAC & $8297-8321$ \\
& 6 & CTA YCT GCG ATT GGT TCC ATC & $9104-9124$ \\
\hline
\end{tabular}

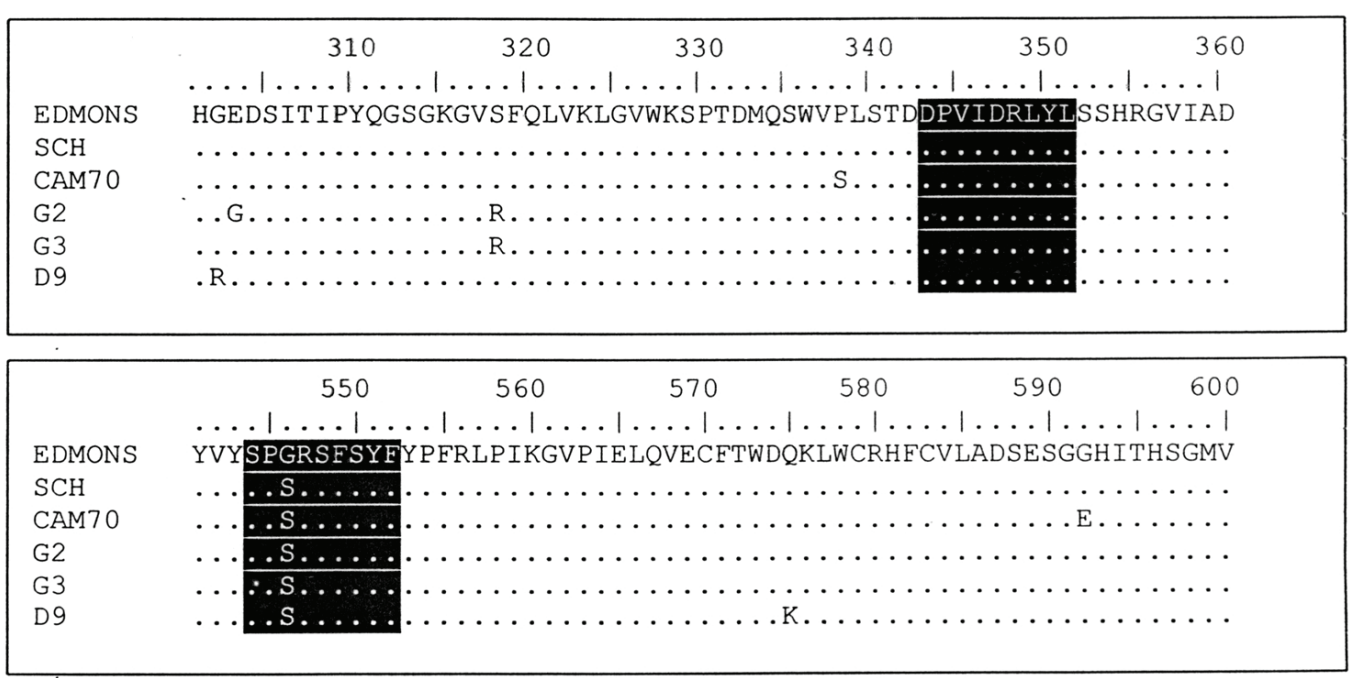

Gambar 2. Epitop CTL pada protein H (bayang hitam) (544-552, 343-351) 
Made Setiawan dkk: Sekuens Asam Amino Epitop Sel B dan Sel T Protein Hemaglutinin Virus Campak

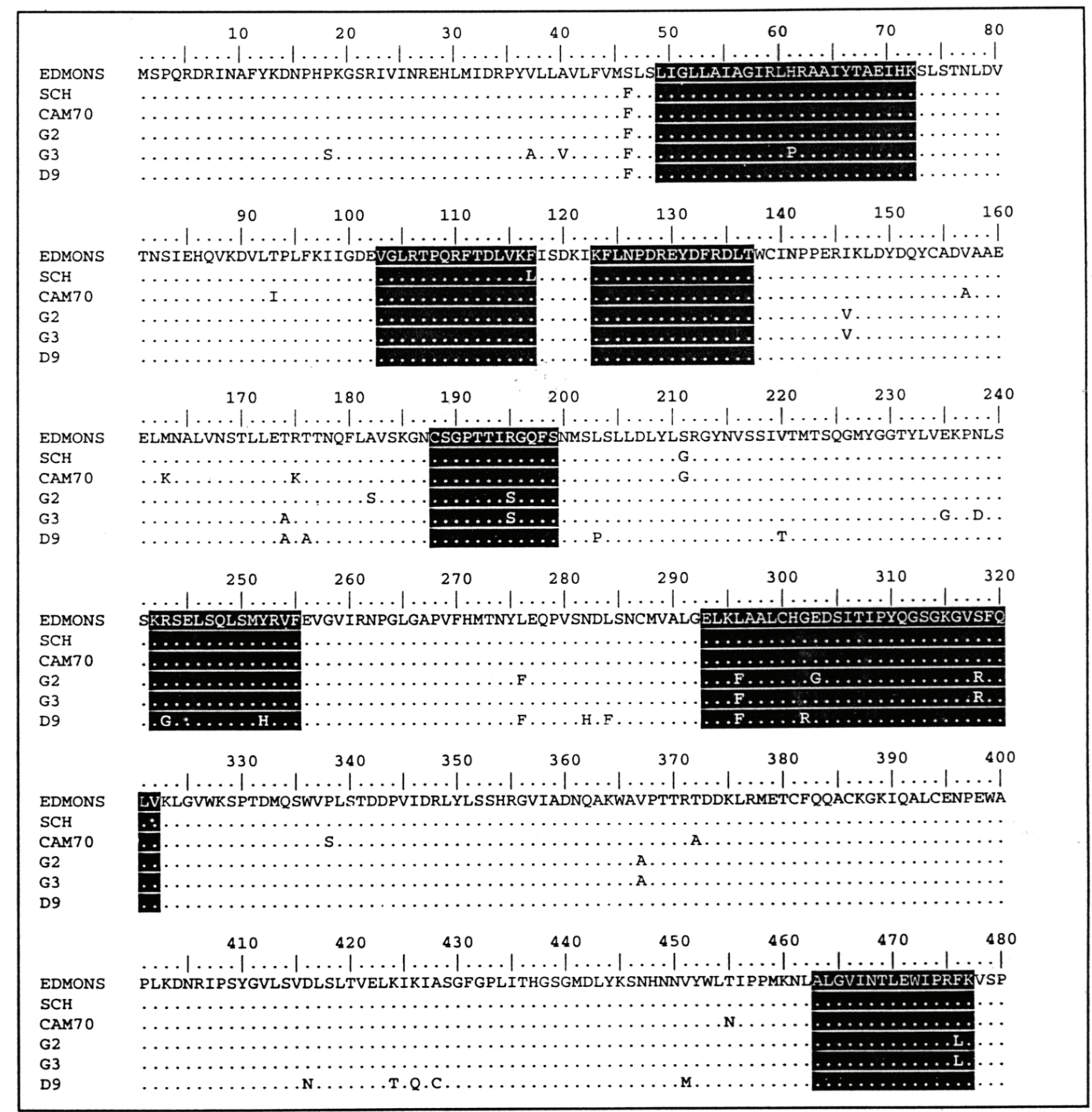

Gambar 3. Epitop sel B pada protein H (bayang hitam).

adalah F (fenilalanin). Perbedaan epitop 188-199 ditemukan asam amino $133 \mathrm{~S}$ (serin) pada G2 dan G3, sedangkan genotipe D9, CAM-70, Schwarz dan Edmonston adalah R (arginin). Perbedaan epitop 242255 ditemukan asam amino $243 \mathrm{G}$ (glisin) pada D9, sedangkan G2, G3, CAM-70, Schwarz dan Edmonston adalah $\mathrm{R}$ (arginin), asam amino $252 \mathrm{H}$ (histidin) pada D9, sedangkan G2, G3, CAM-70, Schwarz dan Edmonston-wt adalah Y (tirosin). Perbedaan epitop 293-307 ditemukan asam amino 296 L (leusin) pada CAM-70, Schwarz dan Edmonston, sedangkan G2, G3 dan D9 adalah F (fenilalanin), asam amino 302
R (arginin) pada genotipe D9, sedangkan G2, G3, CAM-70, Schwarz dan Edmonston adalah G (glisin), asam amino $303 \mathrm{G}$ (glisin) pada G2, sedangkan G3, D9, CAM-70, Schwarz dan Edmonston adalah E (asam glutamat).

Perbedaan epitop 314-322 ditemukan asam mino 318 R (arginin) pada genotipe G2 dan G3, sedangkan genotipe D9, CAM-7, Schwarz dan Edmonston adalah S (serin). Perbedaan epitop 463-478 ditemukan asam amino $476 \mathrm{~L}$ (leusin) pada genotipe G2 dan G3, sedangkan genotipe D9, CAM-70, Schwarz dan Edmonston adalah $\mathrm{F}$ (fenilalanin). 


\section{Pembahasan}

\section{Analisis Epitop CTL dan Epitop sel B pada protein $\mathrm{H}$}

Infeksi virus campak dapat menginduksi respons imun humoral dan respons imun selular. Kedua glikoprotein virus campak dapat menginduksi antibodi netralisasi yang dapat mencegah penyakit secara in vivo, agar dapat kembali sembuh seperti semula diperlukan respons sel T. Hal ini terbukti dari anak yang menderita penyakit a-gamaglobulinemia dapat sembuh dan normal kembali dari penyakit campak, sedangkan anak yang menderita penyakit kelainan sel $\mathrm{T}$ akan mendapat komplikasi bila terserang penyakit campak. Maka peran sel T sangat penting dalam penyembuhan penyakit serta pencegahan terhadap komplikasi. ${ }^{19}$ Untuk pembuatan vaksin, kedua faktor tersebut hendaknya mendapat perhatian khusus agar respon imun yang terbentuk di dalam tubuh optimum, sehingga sasaran program imunisasi dapat tercapai.

Dua jenis epitop CTL yang sudah diketahui pada protein $\mathrm{H}$, epitop 343-351 dan 544-552. ${ }^{16}$ Pada penelitian kami dilakukan analisis dari kedua epitop tersebut. Hasil analisis epitop 343-351 tidak ditemukan perbedaan urutan asam amino antara virus G2, G3, D9, CAM-70, Schwarz dan Edmonston-wt. Perbedaan ditemukan pada epitop CTL 544-552, yaitu asam amino $546 \mathrm{G}$ (glisin) pada virus Edmonston-wt, sedangkan pada genotipe G2, G3, D9, CAM-70 dan Schwarz adalah S (serin). Berdasarkan data tersebut, maka tidak ditemukan perbedaan epitop CTL antara virus vaksin (CAM-70 dan Schwarz) dan virus campak liar di Indonesia (G2, G3 dan D9). Dengan demikian, virus campak liar (G2, G3 dan D9) dan virus vaksin (CAM-70 dan Schwarz) akan memberikan reaksi yang sama terhadap respon CTL.

Hu dkk ${ }^{17}$ menemukan beberapa epitop sel B pada protein $\mathrm{H}$. Obeid $\mathrm{dkk}^{18}$ juga menemukan beberapa epitop sel B pada protein H. Dalam penelitian kami, epitop-epitop yang ditemukan oleh $\mathrm{Hu} \mathrm{dkk}^{17}$ dan Obeid $\mathrm{dkk}^{18}$ dipakai sebagai rujukan untuk menganalisis perbedaan sekuens asam amino antara virus campak liar dan virus vaksin. Dari hasil analisis penjajaran epitop-epitop spesifik sel B (antibodi) antara virus campak liar (G2, G3, dan D9) dan virus vaksin (CAM-70 dan Schwarz) ditemukan perbedaan sekuens asam amino pada beberapa epitop. Epitop yang berbeda adalah epitop 242-255 dengan dua lokasi perbedaan. Asam amino yang berbeda pada ke dua posisi tersebut adalah asam amino dengan sifat yang berbeda. Pada epitop 293-307 terdapat empat lokasi asam amino yang berbeda, dua diantaranya termasuk dalam kelompok sifat asam amino yang berbeda. Pada epitop 314-322 ditemukan 1 lokasi asam amino yang berbeda. Asam amino yang berbeda tersebut ternyata mempunyai sifat yang berbeda. Pada epitop 463-478 hanya ditemukan perbedaan 1 lokasi asam amino, tetapi asam amino yang berbeda termasuk dalam kelompok sifat-sifat asam amino yang sama. Asam amino 211 merupakan asam amino yang penting pada protein $\mathrm{H} .{ }^{20}$ Dari hasil penelitian kami, ditemukan perbedaan asam amino 211 yaitu G (glisin) pada virus vaksin CAM-70, sedangkan virus campak liar (G2, G3 dan D9) adalah (S) serin. Kedua asam amino ini termasuk dalam kelompok sifat asam amino yang berbeda. Akibat adanya perbedaan-perbedaan ini, maka antibodi yang terbentuk tidak homolog sehingga dapat mempengaruhi kemampuan untuk menahan infeksi virus dari genotipe yang berbeda.

\section{Kesimpulan}

Disimpulkan dari hasil analisis sekuens nukleotida gen dan asam amino protein $\mathrm{H}$ ditemukan perbedaan sekuens asam amino epitop sel $\mathrm{T}$ pada protein $\mathrm{H}$ antara virus campak liar dan virus Edmonstone-wt, sedangkan antara virus campak liar dan virus vaksin (CAM-70 dan vaksin Schwarz) tidak ditemukan perbedaan. Ditemukan perbedaan sekuens asam amino pada epitop sel B protein $\mathrm{H}$ antara virus campak liar dan virus vaksin (CAM-70 dan Schwarz), sedangkan antara virus vaksin CAM-70 dan Schwarz tidak ditemukan perbedaan.

\section{Ucapan Terimakasih}

Ucapan terima kasih kami sampaikan kepada bapak Dr I Nyoman Kandun MPH Dirjen P2M dan PL Departemen Kesehatan RI yang telah memberikan dana untuk penelitian ini. Demikian juga ucapan terimakasih kami sampaikan kepada bapak Harun, Joko, Bambang di LitbangKes, Diah Iskandriati, Joko Pamungkas, Uus Saefullah, Silmi di PSSP IPB Bogor, yang semuanya membantu kami sehingga penelitian ini dapat terselesaikan. 


\section{Daftar Pustaka}

1. Nelson JD, Sandusky G, Peck FB. Measles skin test and serologic respons to intradermal measles antigen. JAMA 1966; $198: 185-6$.

2. Fulginiti VA, Arthur JH. Altered reactivity to measles virus. J Pediatr 1969; 75:609-16.

3. Parks CL, Lerch RA, Walpita P, Wang HP, Sidhu MS, Udem SA. Comparison of predicted amino acid sequences of measles virus strains in the Edmonston vaccine lineage. J Virol 2001; 75: 910-20.

4. Tyrell DIJ, Norrby F. Structural polypeptides of measles virus. J GenVirol 1978; 39: 219-29.

5. Rima BK. The proteins of morbilli viruses. J Gen Virol, 1983; 64:1205-19.

6. Griffin DE, Ward BJ, Esolen LM. Pathogesis of measles virus infection: An hypothesis for altered immune responses. J Infec Dis 1994; 170 (Suppl 1) : S24-31.

7. Rose JW, Bellini WJ, McFarlin DE, McFarland HF. Human celluler immune response to measles virus polypeptides. J Virol 1984; 49: 988-91.

8. WHO: Expanded program on immunization. Standardization of the nomenclature for describing the genetic characterization of wild-type measles viruses. Weekly Epidemiological report 2001; 76: 241-8.

9. Tamin A, Rota PA, Wang Z, Heath JL, Anderson LJ, Bellini WJ. Antigenic analysis of current wild type and vaccine strains of measles virus. J Infect Dis 1994; 170:795-801.

10. Bellini WJ, Rota JS, Rota PA. Virology of measles virus. J Infct Dis 1994; 170 (suppl.1):S15-23.

11. Wong TC, Ayata M, Ueda S, Hirano A. Role of biased hypermutation in evolution of subacute sclerosing panencephlitis virus from progenitor acute measles virus.
J Virol 1991; 65:2191-9.

12. Taylor MJ, Godfrey E, Baczko K, ter meulen V, Wild TF, Rima BK. Identification of several different lineages of measles virus. J Gen Virol 1991; 72:83-8.

13. Litbangkes Depkes RI. Laporan hasil genotype virus campak yang dikirim oleh WHO, 2002.

14. Komase K, Suzuki N, Nakayama T, Miki K, Kawanishi R, Fukuda K. Genom sequence of measles virus. 2001; NCBI no. accession: AB046218.

15. Coligan JE, Kruisbeek AM, Margulies DH, Shevach EM, Strober W. Current Protocols in Immunology. Vol. I. National Institut of Health; Published by Current Protocols Wiley, 1996.

16. Beauverger P, Chadwick J, Buckland R, Wild TF. Serotype-spesific and canine distemper virus crossreactive $\mathrm{H}-2 \mathrm{KK}$-restricted cytotoxic $\mathrm{T}$ lymphocyte epitopes in the measles virus nucleoprotein. Virology 1994; 203: 172-7.

17. $\mathrm{Hu}$ A, Sheshberandaran H, Norbby E, Kovamees J. Moleculer characterization of epitope on the measles virus hemaglutinin protein. Virology 1993; 192: 351-4.

18. Obeid OE, Partidos CD, Steward MW. Analysis of the antigenic profile of measles virus haemagglutinin in mice and humans using overlapping synthetic peptides. Virus Res 1994; 32: 69-84.

19. Aicardi J, Goutieres F, Arseneo-Nunes ML, Lebon P. Acute measles encephalitis In children with immunosuppression. Pediatrics 1977; 59: 232-9.

20. Nicacio C deC, Williamson A, Parren PWHI, Lundkvist A, Burton DR, Bjorling E. Neutralizing human Fab fragments against measles virus recovered by Phage display. Didapat dari: http/jvi.asm.org/cq/content/ full/76/1/251, 2001 